\title{
Groundwater Quality in the Glacial Aquifer System, United States
}

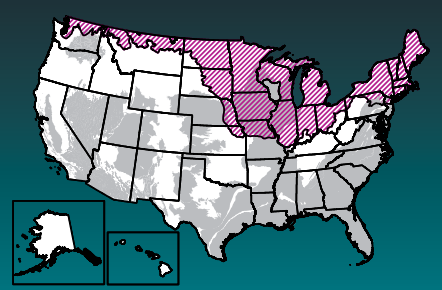

Groundwater provides nearly $\mathbf{5 0}$ percent of the Nation's drinking water. To help protect this vital resource, the U.S. Geological Survey (USGS) National Water-Quality Assessment (NAWQA) Project assesses groundwater quality in aquifers that are important sources of drinking water (Burow and Belitz, 2014). The glacial aquifer system constitutes one of the important areas being evaluated.

\section{Background}

Sand and gravel aquifers of the glacial aquifer system underlie an area of the northern contiguous United States with a population of more than 98 million people in parts of 25 states. The glacial aquifer system ranks first in the Nation as a source of groundwater for both public supply and domestic supply, with about 2.6 billion gallons per day being pumped for those uses (Arnold and others, 2017a). Land use overlying the aquifer system is mostly agricultural in the central and west-central regions and mostly undeveloped in the east and west. Large urban areas also are in the area underlain by the glacial aquifer system, with nearly one-third of the United States population living in this area (Warner and Ayotte, 2014).

The glacial aquifer system consists of permeable, unconsolidated sediments left behind by continental glaciers in the northern United States. The wide variety of glacial depositional processes and environments resulted in the accumulation of heterogeneous deposits across the area (Warner and Ayotte, 2014). Regionally, however, there are some general similarities in depositional setting and sediment type. In the east and the west, glacial sediments fill valleys and cover broad low-lying areas, with sediments typically ranging in thickness from less than 50 to 200 feet (Olcott, 1995). Discontinuous layers of sand and gravel in these settings provide the most productive water supplies from the glacial aquifer system in the east and west. In the central and west-central regions, the glacial aquifer system consists of thick sequences of coarse- and fine-grained glacial sediments that fill and obscure preexisting bedrock valleys (with sediments as much as 400 feet in thickness; Whitehead, 1994). Unsorted, fine-grained till sediments overlie the buried valleys and contain discontinuous layers of more permeable sediments. Northern areas in the central region also contain thick sequences of glacial-lake deposits. Recharge to the glacial system is primarily from precipitation or inflow from adjacent aquifers; discharge is typically to streams and other surface waters (Olcott, 1992, 1995).

Groundwater quality in the glacial aquifer was evaluated by sampling 90 spatially distributed publicsupply wells in a Principal Aquifer Study (Burow and Belitz, 2014). Public-supply wells in the glacial aquifer system typically consist of casing extending downward from the land surface and a perforated (screened) interval at the bottom. The length of the perforated intervals for the 90 sampled wells ranged from about 6 to 80 feet, and the total well depths ranged from about 30 to 420 feet. Water-quality data from these wells were used to estimate the percentage of the study area with concentrations that are 40 high, moderate, and low with respect to constituent benchmarks. The accuracy of the estimates depends upon the distribution and number of wells, not on the size of the area (Belitz and others, 2010). Samples were analyzed for a large number of waterquality constituents derived from natural and human sources.

\section{Overview of Water Quality}
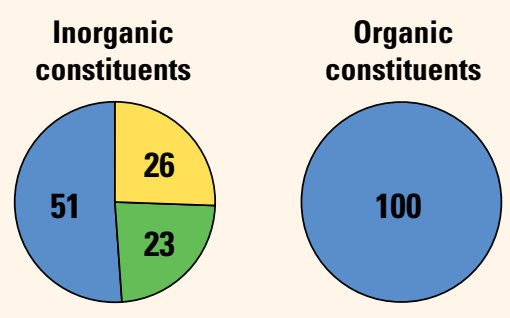

\section{CONSTITUENT CONCENTRATIONS}

\section{$\bigcirc$ High $\bigcirc$ Moderate $\bigcirc$ Low or not detected \\ Values are a percentage of the study area with concentrations in the three specified categories. Percentages might not sum to 100 because of rounding.}

Principal Aquifer Studies are designed to evaluate groundwater used for public supply prior to any treatment. Groundwater quality is assessed by comparing concentrations to benchmarks established for drinking-water quality. Benchmarks and definitions of high, moderate, and low concentrations are discussed in the inset box on page 3 . Water from 74 percent of the wells sampled did not have high concentrations of any constituent with a human-health benchmark.

Many inorganic constituents are naturally present in groundwater. The concentrations of inorganic constituents can be affected by natural processes as well as by human activities. One or more inorganic constituents were detected at high concentrations in about 26 percent of the study area and at moderate concentrations in about 23 percent.

Organic constituents derived from human activities are used in household, business, industrial, and agricultural products. They can enter the environment through normal usage, spills, or improper disposal. Organic constituents were not detected at high or moderate concentrations in the study area. 


\section{Results: Groundwater Quality at the Depth Zone Used for Public Supply in the Glacial Aquifer System}

\section{INORGANIC CONSTITUENTS}

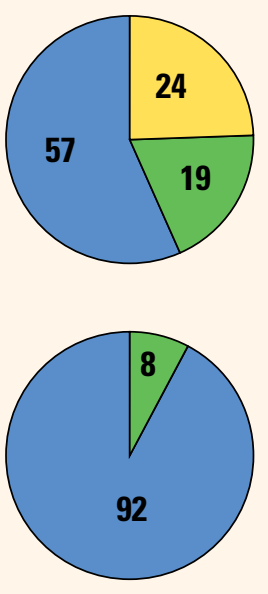

Trace elements

\section{Radioactive constituents}

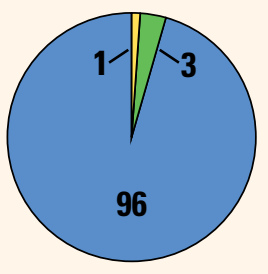

\section{Nutrients}

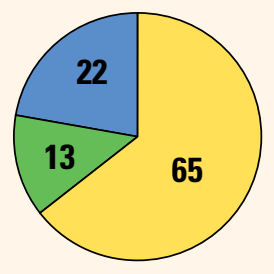

\section{Inorganic Constituents With Human-Health Benchmarks}

Trace elements and major and minor ions are naturally present in the minerals of rocks, soils and sediments, and in the water that comes into contact with those materials. Samples were analyzed for 34 trace elements and major and minor ions, of which 19 have humanhealth benchmarks. Constituents from this group were detected at high concentrations in about 24 percent of the study area (the depth zone used for public supply) and at moderate concentrations in about 19 percent. Manganese, arsenic, and strontium were the only constituents in this group that were detected at high concentrations.

Radioactivity is the release of energy or energetic particles during spontaneous decay of unstable atoms. Humans are continuously exposed to small amounts of natural radioactivity. Most of the radioactivity in groundwater comes from the decay of isotopes of uranium and thorium that are naturally present in minerals in aquifer materials. Samples were analyzed for eight radioactive constituents, of which four have human-health benchmarks. Radioactive constituents were not present at high levels but were present at moderate concentrations in about 8 percent of the study area.

Nutrients are naturally present at low concentrations in groundwater; high and moderate concentrations (relative to human-health benchmarks) generally result from human activities. Samples were analyzed for five nutrients, of which two have human-health benchmarks. Common sources of nutrients, aside from soils, include fertilizer applied to crops and landscaping, seepage from septic systems, and human and animal waste. Nutrients were detected at high concentrations in about 1 percent of the study area and at moderate concentrations in about 3 percent. Nitrate was the only nutrient detected at moderate or high concentrations.

\section{Inorganic Constituents and Field Measurements With Non-Health Benchmarks}

(Not included in water-quality overview charts shown on the front page)

Some constituents affect the aesthetic properties of water, such as taste, color, and odor, or can create nuisance problems, such as staining and scaling. The benchmarks used for these constituents were non-regulatory secondary maximum contaminant level (SMCL) benchmarks established for public drinking water. Some constituents, such as fluoride and manganese, have human-health benchmarks and SMCLs. Samples were analyzed for 11 constituents that have SMCLs. One or more of these were present at high concentrations or values relative to the SMCL in about 65 percent of the study area and at moderate concentrations in about 13 percent.

Total dissolved solids (TDS) concentration is a measure of the salinity of the groundwater, based primarily on the concentrations of ions, and all water naturally contains TDS as a result of the weathering and dissolution of minerals in rocks and sediments. Concentrations of TDS can be high because of natural factors or as a result of human activities, such as applications to the land surface of road salt, fertilizers, or other chemicals in urban or agricultural areas. Most of the study area had high (28 percent) or moderate (40 percent) concentrations of TDS. Sulfate and chloride were present at high concentrations in about 7 and 1 percent of the study area, respectively, and at moderate concentrations in 14 and 3 percent, respectively.

Anoxic conditions in groundwater (low amounts of dissolved oxygen) can result in the release of iron and manganese in minerals to the groundwater. Manganese was present at high concentrations relative to the SMCL in about 50 percent of the study area and at moderate concentrations in 9 percent. Iron was present at high concentrations relative to the SMCL in about 47 percent of the study area and at moderate concentrations in 7 percent.

In some areas, the $\mathrm{pH}$ of the groundwater was not within the SMCL range of 6.5 to 8.5. The $\mathrm{pH}$ did not meet the standard in 2 percent of the study area because it was less than 6.5 , which is acidic and potentially corrosive. 


\section{Results: Groundwater Quality at the Depth Zone Used for Public Supply in the Glacial Aquifer System}

\section{ORGANIC CONSTITUENTS}

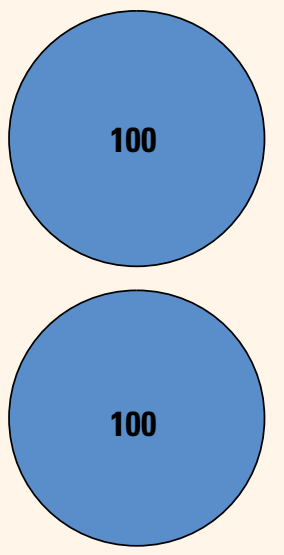

\section{Volatile Organic Compounds With Human-Health Benchmarks}

VOCs

Volatile organic compounds (VOCs) are present in many household, commercial, industrial, and agricultural products and are characterized by their tendency to volatilize (evaporate). Samples were analyzed for 90 VOCs, of which 38 have human-health benchmarks. No VOCs were detected at high or moderate concentrations in the study area.

\section{Pesticides With Human-Health Benchmarks}

Pesticides

Pesticides, including herbicides, insecticides, and fumigants, are applied to crops, gardens and lawns, around buildings, and along roads to help control unwanted vegetation (weeds), insects, fungi, and other pests. Samples were analyzed for 227 pesticide compounds (pesticides and their breakdown products), of which 119 have human-health benchmarks. Pesticides were not detected at high or moderate concentrations in the study area.

\section{BENCHMARKS FOR EVALUATING GROUNDWATER QUALITY}

The USGS NAWQA Project uses benchmarks established for drinking water to provide context for evaluating the quality of untreated groundwater. The quality of water received by consumers can be different, because after withdrawal, groundwater may be treated prior to delivery. Federal regulatory benchmarks for protecting human health are used for this evaluation of water quality when available. Otherwise, non-regulatory human-health benchmarks and non-regulatory aesthetic benchmarks are used. Not all constituents analyzed have benchmarks and, thus, are not considered in this context. Out of 55 inorganic constituents and properties and 317 organic constituents, 24 and 157, respectively, have human-health

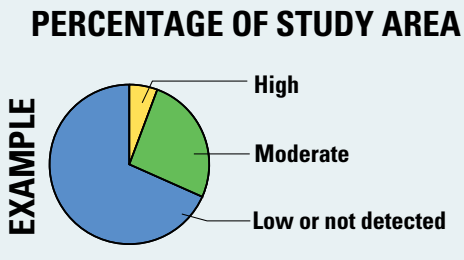

Values are a percentage of the study area with concentrations in the three specified categories. Percentages might not sum to 100 because of rounding. benchmarks.

Concentrations are considered high if they are greater than a human-health benchmark (Toccalino and others, 2014) or SMCL. For inorganic constituents, concentrations are moderate if they are greater than one-half of a benchmark. For organic constituents, concentrations are moderate if they are greater than one-tenth of a benchmark; this lower threshold is used because organic constituents are generally less prevalent and have lower concentrations relative to benchmarks than inorganic constituents (Toccalino and others, 2004).

\section{Benchmark Type and Value for Selected Constituents}

This table presents benchmarks for those constituents detected at high concentrations in the glacial aquifer system. Benchmark types are regulatory U.S. Environmental Protection Agency maximum contaminant levels (MCLs), non-regulatory health-based screening levels (HBSLs), and non-regulatory secondary maximum contaminant levels (SMCLs).

[Abbreviations: ppb, part per billion or microgram per liter $(\mu \mathrm{g} / \mathrm{L}) ; \mathrm{ppm}$, part per million or milligram per liter $(\mathrm{mg} / \mathrm{L})$ ]

\begin{tabular}{|c|c|c|c|c|c|}
\hline \multirow{2}{*}{ Constituent } & \multicolumn{2}{|c|}{ Benchmark } & \multirow{2}{*}{ Constituent } & \multicolumn{2}{|c|}{ Benchmark } \\
\hline & Type & Value & & Type & Value \\
\hline Manganese & HBSL & $300 \mathrm{ppb}$ & Manganese & SMCL & $50 \mathrm{ppb}$ \\
\hline Arsenic & MCL & $10 \mathrm{ppb}$ & Iron & SMCL & $300 \mathrm{ppb}$ \\
\hline Strontium & HBSL & $4,000 \mathrm{ppb}$ & Total dissolved solids (TDS) & SMCL & $500 \mathrm{ppm}$ \\
\hline \multirow[t]{2}{*}{ Nitrate } & MCL & $10 \mathrm{ppm}$ & Sulfate & SMCL & $250 \mathrm{ppm}$ \\
\hline & & & Chloride & SMCL & $250 \mathrm{ppm}$ \\
\hline
\end{tabular}




\section{Manganese Concentrations Vary by Aquifer Region}

Manganese is a naturally occurring trace element known for causing aesthetic concerns with water supplies. More recently manganese has also been associated with adverse humanhealth effects (Homoncik and others, 2010; Bouchard and others, 2011), and an HBSL has been established at 300 micrograms per liter $(\mu \mathrm{g} / \mathrm{L})$. In the glacial aquifer system, high concentrations of manganese are particularly prevalent in the west-central region, which is characterized by thick sequences of mostly fine-grained glacial sediments (Warner and Ayotte, 2014). Low dissolvedoxygen concentrations in groundwater in this setting favor the release of manganese from aquifer materials into groundwater. In contrast, high concentrations of manganese were least prevalent in the east and west regions, which are characterized by thinner sequences of coarser-grained glacial sediments (Warner and Ayotte, 2014). Groundwater in these settings is more likely to be oxygenated; therefore, manganese is less likely to be released into groundwater.

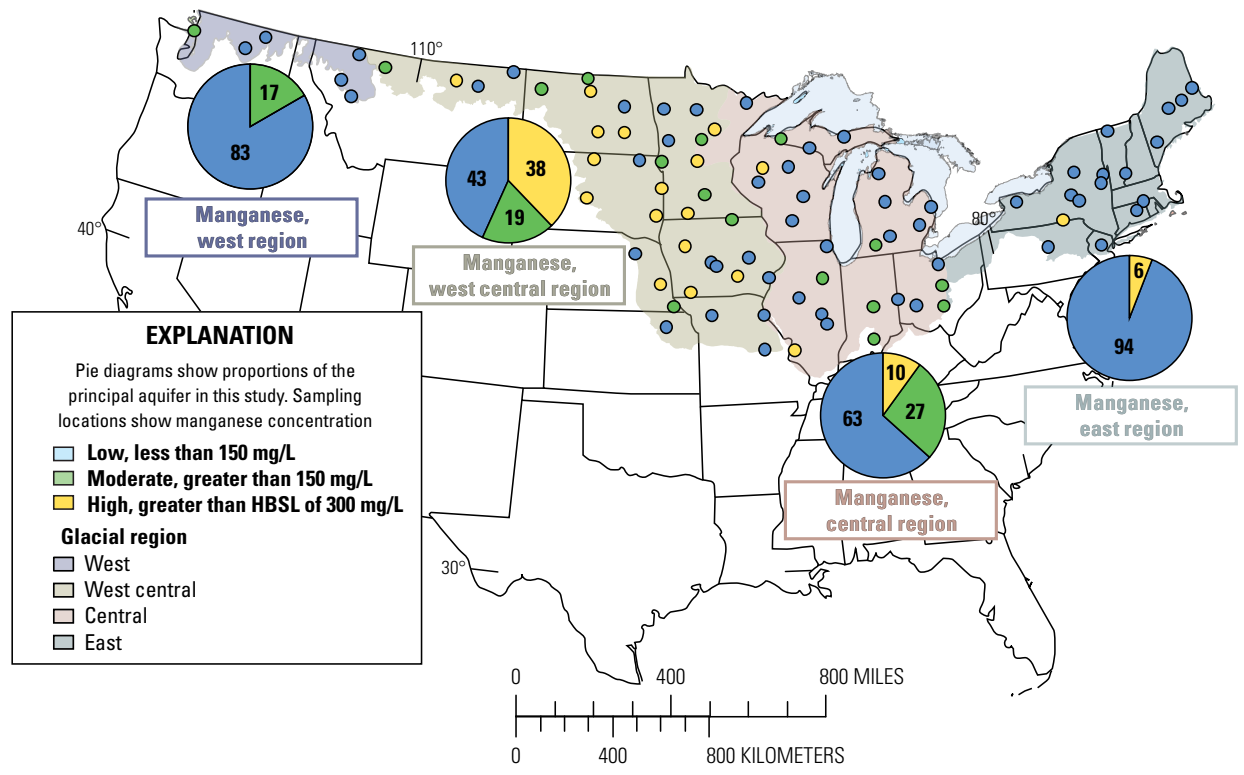

By Paul Stackelberg

\section{SELECTED REFERENCES}

Arnold, T.L., Bexfield, L.M., Musgrove, MaryLynn, Lindsey, B.D., Stackelberg, P.E., Barlow, J.R., DeSimone, L.A., Kulongoski, J.T., Kingsbury, J.A., Ayotte, J.D., Fleming, B.J., and Belitz, Kenneth, 2017a, Groundwater-quality data from the National Water-Quality Assessment Project, January through December 2014 and select quality-control data from May 2012 through December 2014: U.S. Geological Survey Data Series 1063, 83 p., https://doi.org/10.3133/ds1063.

Arnold, T.L., Bexfield, L.M., Musgrove, MaryLynn, Lindsey, B.D., Stackelberg, P.E., Barlow, J.R., DeSimone, L.A., Kulongoski, J.T., Kingsbury, J.A., Ayotte, J.D., Fleming, B.J., and Belitz, Kenneth, 2017b, Datasets from groundwater-quality data from the National Water-Quality Assessment Project, January through December 2014 and select quality-control data from May 2012 through December 2014: U.S. Geological Survey data release, https://doi.org/10.5066/F7W0942N.

Belitz, K., Jurgens, B., Landon, M.K., Fram, M.S., and Johnson T., 2010, Estimation of aquifer scale proportion using equal area grids-Assessment of regional scale groundwater quality: Water Resources Research., v. 46, 14 p., doi:10.1029/2010WR009321.

Bouchard, M.F., Sauvé, S., Barbeau, B., Legrand, M., Brodeur, M., Bouffard, T., Limoges, E., Bellinger, D.C., and Mergler, D., 2011, Intellectual impairment in school-age children exposed to manganese from drinking water: Environmental Health Perspectives, v. 119 , no. 1 , p. 138-143.

Burow, K.R., and Belitz, Kenneth, 2014, Groundwater studies-Principal aquifer surveys: U.S. Geological Survey Fact Sheet 2014-3024, 2 p., https://dx.doi.org/10.3133/fs20143024.

DeSimone, L.A., McMahon, P.B., and Rosen, M.R., 2014, The quality of our Nation's waters - Water quality in principal aquifers of the United States, 1991-2010: U.S. Geological Survey Circular 1360, 151 p., https://dx.doi.org/10.3133/cir1360.

Homoncik, S.C., MacDonald, A.M., Heal, K.V., Dochartaigh, B.É.Ó., and Ngwenya, B.T., 2010, Manganese concentrations in Scottish groundwater: Science of the Total Environment, v. 408, p. 2467-2473.

Olcott, P.G., 1992, Ground water atlas of the United States-Iowa, Michigan, Minnesota, Wisconsin: U.S. Geological Survey Hydrologic Atlas 730-J, accessed January 4, 2016, at https://pubs.usgs.gov/ha/ha730/ch j/index.html.

Olcott, P.G., 1995, Ground water atlas of the United States - Connecticut, Maine, Massachusetts, New Hampshire, New York, Rhode Island, Vermont: U.S. Geological Survey Hydrologic Atlas 730-M, accessed January 4, 2016, at https://pubs.usgs.gov/ha/ha730/ch_m/index.html.

Toccalino, P.L., Norman, J.E., Phillips, R.H., Kauffman, L.J., Stackelberg, P.E., Nowell, L.H., Krietzman, S.J., and Post, G.B., 2004, Application of health-based screening levels to ground-water quality data in a state- scale pilot effort: U.S. Geological Survey Scientific Investigations Report 2004-5174, 64 p.

Toccalino, P.L., Norman, J.E., and Schoephoester, K.M., 2014, Health-based screening levels for evaluating water-quality data: U.S. Geological Survey National Water-Quality Assessment Program website, doi:10.5066/F71C1TWP, accessed at https://water.usgs.gov/nawqa/HBSL.

Warner, K.L., and Ayotte, J.D., 2014, The quality of our Nation's waters-Water quality in the glacial aquifer system, northern United States, 1993-2009: U.S. Geological Survey Circular 1352, 116 p., https://dx.doi.org/10.3133/cir1352.

Whitehead, R.L., 1994, Ground water atlas of the United States-Idaho, Oregon, Washington: U.S. Geological Survey Hydrologic Atlas 730-H, accessed January 4, 2016, at https://pubs.usgs.gov/ha/ha730/ch_h/index.html.

\section{Principal Aquifer Studies}

The USGS NAWQA Project has been assessing the quality of groundwater since 1991. The NAWQA studies include Land Use Studies (LUS), Major Aquifer Studies (MAS), and Principal Aquifer Studies (PAS). These three study types are based on sampling networks of wells distributed across an area of interest. The LUS networks typically consist of observation wells that are relatively shallow, MAS networks typically consist of domestic-supply wells that are intermediate in depth, and PAS networks typically consist of public-supply wells that are relatively deep. A national synthesis of shallow and intermediate depth groundwater quality was reported by DeSimone and others (2014), and a regional synthesis of shallow and intermediate depth groundwater quality from the glacial aquifer system was reported by Warner and Ayotte (2014). This fact sheet provides a summary of PAS data for 90 public-supply wells sampled in 2013 and 2014 in the glacial aquifer system (data available in Arnold and others, 2017b).

The PAS assessments like this one allow for the comparison of constituent concentrations in untreated groundwater with benchmarks established for the protection of human health and for aesthetic qualities of drinking water and also provide a basis for comparison of groundwater quality among the principal aquifers. The data collected by the NAWQA Project include chemical analyses generally not available as part of regulatory compliance monitoring, including measurements at concentrations much lower than the levels used as human-health benchmarks and measurements of constituents that can be used to trace the sources and movement of groundwater.

\section{For more information}

Technical reports and hydrologic data collected for the USGS NAWQA Project may be obtained from:

\section{NAWQA Chief Scientist}

U.S. Geological Survey

12201 Sunrise Valley Drive, MS 413

Reston, VA 20192-0002

Email: nawqapublicinfo@usgs.gov

WEB: https://water.usgs.gov/nawqa/

ISSN 2327-6916 (print)

ISSN 2327-6932 (online)

https://doi.org/10.3133/fs2017305 